\title{
Psychromonas ingrahamii sp. nov., a novel gas vacuolate, psychrophilic bacterium isolated from Arctic polar sea ice
}

Correspondence

James T. Staley

jtstaley@u.washington.edu

\author{
Ann J. Auman, ${ }^{1}$ Jennifer L. Breezee, ${ }^{2} \dagger$ John J. Gosink, ${ }^{2} \ddagger$ Peter Kämpfer ${ }^{3}$ \\ and James T. Staley ${ }^{2}$ \\ ${ }^{1}$ Department of Biology, Pacific Lutheran University, Tacoma, WA 98447, USA \\ ${ }^{2}$ Department of Microbiology, University of Washington, Seattle, WA 98195, USA \\ ${ }^{3}$ Institut für Angewandte Mikrobiologie, Justus-Liebig-Universität Giessen, Heinrich-Buff-Ring \\ 26-32, D-35392 Giessen, Germany
}

\begin{abstract}
A gas vacuolate bacterium, designated strain $37^{\top}$, was isolated from a sea ice core collected from Point Barrow, Alaska, USA. Cells of strain $37^{\top}$ were large (6-14 $\mu \mathrm{m}$ in length), rod-shaped, contained gas vacuoles of two distinct morphologies, and grew well at $\mathrm{NaCl}$ concentrations of $1-10 \%$ and at temperatures of -12 to $10^{\circ} \mathrm{C}$. The DNA G $+\mathrm{C}$ content was $40 \mathrm{~mol} \%$. Whole-cell fatty acid analysis showed that $16: 1 \omega 7 c$ comprised $67 \%$ of the total fatty acid content. Phylogenetic analysis of $16 \mathrm{~S}$ rRNA gene sequences indicated that this bacterium was closely related to members of the genus Psychromonas, with highest sequence similarity (96.8\%) to Psychromonas antarctica. Phenotypic analysis differentiated strain $37^{\top}$ from $P$. antarctica on the basis of several characteristics, including cell morphology, growth temperature range and the ability to hydrolyse polymers. DNA-DNA hybridization experiments revealed a level of relatedness of $37 \%$ between strain $37^{\top}$ and $P$. antarctica, providing further support that it represents a distinct species. The name Psychromonas ingrahamii sp. nov. is proposed for this novel species. The type strain is $37^{\top}\left(=\right.$ CCUG $51855^{\top}=$ CIP $\left.108865^{\top}\right)$.
\end{abstract}

Most of the Earth's biosphere never reaches temperatures above $5{ }^{\circ} \mathrm{C}$ and is home to a diverse group of microorganisms termed psychrophiles, having minimum, optimum and maximum growth temperatures at or below 0,15 and $20^{\circ} \mathrm{C}$, respectively (Morita, 1975). One psychrophilic ecosystem, polar sea ice, comprises $7-13 \%$ of the Earth's surface at its maximum (Maykut, 1985; Parkinson \& Gloersen, 1993; Weeks \& Ackley, 1982). Polar sea ice is seasonably variable and its formation begins during polar winter as the ocean surface waters freeze, forming a surface slush termed 'frazil ice'. This ice consolidates into circular sheets of 'pancake ice', which become colonized by microbes that eventually establish the sea ice microbial community (SIMCO) (Nichol \& Allison, 1997; Staley \& Gosink, 1999; Garrison et al., 1983). Polar sea ice is semisolid, containing channels of brine formed during ice crystallization.

tPresent address: Department of Special Bacteriology, Washington State Department of Health, Shoreline, WA 98155, USA.

‡Present address: Department of Bioinformatics, Amgen, Inc., Seattle, WA 98119, USA.

Abbreviations: PUFA, polyunsaturated fatty acid; SIMCO, sea ice microbial community.

The GenBank/EMBL/DDBJ accession number for the 16S rRNA gene sequence of strain $37^{\top}$ is $\mathrm{U} 73721$.
Brine pockets may reach salinity levels of $150 \%$ (Maykut, 1985), providing a liquid-phase environment at subzero temperatures.

Sea ice is an active environment with large gradients in light, temperature, nutrient availability and salinity, all of which change seasonally (Eicken, 1992). The SIMCOs are typically concentrated in the lower $10-20 \mathrm{~cm}$ of a sea ice column, at the ice-water interface, where both sufficient nutrients from the water column and sufficient surface light are present (Staley \& Gosink, 1999). The SIMCOs are stratified, containing large varieties of both eukaryotes and prokaryotes. Recent attempts to characterize the bacterial component of SIMCOs have revealed great diversity. To our knowledge, six new genera of the phylum Bacteroidetes (Gosink et al., 1998; Bowman et al., 1998a, 1997, 2003; Bowman \& Nichols, 2002) and three new genera of Proteobacteria (Gosink et al., 1997; Irgens et al., 1996; Bowman et al., 1998b) have been identified within or near the SIMCO, along with known Gram-positive genera (Junge et al., 1998).

Among the SIMCOs, gas vacuolate heterotrophs have been discovered in high numbers from both the Arctic and the Antarctic (Gosink et al., 1993; Staley et al., 1989), located either in the water column below or in the ice above the 
nutrient-rich SIMCO band (Gosink et al., 1993). Gas vacuoles contain small, rigid, proteinaceous subunit vesicles that are gas-permeable, reducing cell density as compared with the cytoplasm, and thereby providing buoyancy (Walsby, 1972). Gas vesicles act as organelles of motility, regulating the vertical movement of cells via their synthesis and degradation (Staley, 1980). Although gas vacuolate bacteria in polar sea ice are prevalent and phylogenetically diverse, belonging to the Alpha-, Beta- and Gammaproteobacteria and to the Bacteroidetes (Gosink \& Staley, 1995), the function of gas vacuoles in this environment remains unknown.

Recently, we reported that a bacterial isolate, designated strain $37^{\mathrm{T}}$, isolated from a sea ice core from Point Barrow, Alaska, USA, could grow at subfreezing temperatures, with a generation time of $240 \mathrm{~h}$ at $-12^{\circ} \mathrm{C}$, the lowest recorded growth temperature of any organism verified by a growth curve (Breezee et al., 2004). Strain $37^{\mathrm{T}}$ was considered to represent a novel species, which was provisionally named Psychromonas ingrahamii sp. nov. It is most similar to Psychromonas antarctica and other members of the genus Psychromonas, a group of psychrophiles having a wide variety of physiological characteristics including piezophily, facultative psychrophily and halophily (Breezee et al., 2004; Mountfort et al., 1998; Kawasaki et al., 2002; Nogi et al., 2002; Xu et al., 2003; Groudieva et al., 2003; Ivanova et al., 2004). Here we report additional information for this sea ice isolate to justify recognition of this novel species.

Strain $37^{\mathrm{T}}$ was isolated in May 1991 from Elson Lagoon (Point Barrow, Alaska) about $130 \mathrm{~cm}$ from the ice-water interface of a $1.8 \mathrm{~m}$ ice core (Gosink et al., 1993). Ordal's sea water cytophaga medium $\left(\mathrm{SWC}_{\mathrm{m}}\right)$ prepared in full-strength artificial sea water (ASW) was used for the isolation and routine growth of strain $37^{\mathrm{T}}$ (Irgens et al., 1989). Colonies on plates were white, circular, smooth and convex, with an entire margin. Phenotypic characteristics of strain $37^{\mathrm{T}}$ are summarized in Table 1.

Cell size, shape and the presence of gas vacuoles were determined for cells grown in Difco marine broth 2216 (Becton Dickinson) via phase contrast microscopy using a Zeiss Photomicroscope I. Electron micrographs were obtained of unstained whole cells by using a Zeiss EM900 transmission electron microscope at $50 \mathrm{kV}$. Cells of strain $37^{\mathrm{T}}$ were unusually large, ranging from 6 to $14 \mu \mathrm{m}$ long by $1 \cdot 25$ to $1.5 \mu \mathrm{m}$ wide (Fig. 1; Breezee et al., 2004), and were arranged singly, in pairs or in short chains. Motility was examined by incubation of strain $37^{\mathrm{T}}$ in liquid $\mathrm{SWC}_{\mathrm{m}}$ for 12 days with periodic examination by phase contrast microscopy, and cells were found to be non-motile. Gas vacuoles were also visible, appearing as bright, refractive areas inside cells (Fig. 1). Electron microscopy revealed two distinct morphologies of gas vacuoles: numerous short, wide cylinders with conical tips; and rare, longer but narrower cylinders with conical ends (Fig. 1b). The presence of two gas vacuole types is unusual, having been reported before only in the halophilic archaeon Halobacterium halobium (Walsby, 1994).
The range of temperatures allowing growth of strain $37^{\mathrm{T}}$ was determined by observation of growth on $\mathrm{SWC}_{\mathrm{m}}$ plates at $5,10,15$ and $20^{\circ} \mathrm{C}$ for 8 days. Growth at subzero temperatures was also tested using liquid $\mathrm{SWC}_{\mathrm{m}}$. Strain $37^{\mathrm{T}}$ was psychrophilic, growing at temperatures from -12 to $10^{\circ} \mathrm{C}$ with a generation time of $240 \mathrm{~h}$ at $-12^{\circ} \mathrm{C}$ (Breezee et al., 2004). No growth was observed at $15^{\circ} \mathrm{C}$. Attempts to grow strain $37^{\mathrm{T}}$ at $-15^{\circ} \mathrm{C}$ were unsuccessful because the culture medium routinely froze. The true minimum growth temperature may in fact be lower than $-12^{\circ} \mathrm{C}$.

The $\mathrm{pH}$ range for growth was tested using $\mathrm{SWC}_{\mathrm{m}}$ buffered to various $\mathrm{pH}$ values with $25 \mathrm{mM}$ solutions of the following buffers: MES, pH 5.7; ACES, pH 6.6; TAPSO, pH 7·4; TAPS, pH 8·3; CHES, pH 9.0) (Dyksterhouse et al., 1995). Growth at each $\mathrm{pH}$ was determined turbidometrically using a Bausch and Lomb 20-D spectrophotometer at $600 \mathrm{~nm}$. Growth was observed at near neutral $\mathrm{pH}$ values $(\mathrm{pH} 6 \cdot 5,6 \cdot 8$ and $7 \cdot 4)$, but not at moderately acidic $(\mathrm{pH} 5 \cdot 0)$ or basic $(\mathrm{pH} 8 \cdot 3,9 \cdot 0)$ values.

Requirement for and tolerance to $\mathrm{NaCl}$ were determined by observing growth on CLED agar (Difco) supplemented with $0-22 \% \mathrm{NaCl}$. Strain $37^{\mathrm{T}}$ required $\mathrm{NaCl}$ for growth, showing no growth at $0 \% \mathrm{NaCl}$. It grew well at $1-12 \% \mathrm{NaCl}$, and weak growth was observed at $\mathrm{NaCl}$ concentrations as high as $20 \%$.

The ability of strain $37^{\mathrm{T}}$ to use a particular substrate as its sole carbon source was tested at substrate concentrations of $0.2 \%$ in $\mathrm{SWC}_{\mathrm{m}}$ in microtitre plate wells. Strain $37^{\mathrm{T}}$ was inoculated in triplicate and incubated for 21 days at $5{ }^{\circ} \mathrm{C}$. Growth was determined by measuring the absorbance at $600 \mathrm{~nm}$ using a DeltaSoft II microplate reader. Strain $37^{\mathrm{T}}$ was able to use a wide variety of carbon sources, as detailed in the species description later. Sugar fermentation was tested using the Hugh-Leifson method (Gerhardt et al., 1981). BBL brand OF basal medium was dissolved in ONR7a salt solution (Dyksterhouse et al., 1995). Each carbon source was diluted to a concentration of $1 \%$. Vibrio splendi$d u s$ and inoculated medium without added carbon source were used as positive and negative controls, respectively. Gas production from glucose metabolism was detected by growing strain $37^{\mathrm{T}}$ in liquid $\mathrm{SWC}_{\mathrm{m}}$ supplemented with glucose into which Durham tubes were placed for gas detection. Strain $37^{\mathrm{T}}$ was facultatively anaerobic and fermented several carbon sources, including lactose, sucrose, D-mannitol, salicin, maltose, trehalose, cellobiose, D-galactose, melibiose and D-glucose (without gas production), but not dulcitol, myo-inositol, D-sorbitol, L-arabinose or D-xylose.

Biochemical tests were performed using standard methodology (Gerhardt et al., 1981). For these tests, cultures of strain $37^{\mathrm{T}}$ were grown in $\mathrm{SWC}_{\mathrm{m}}$ supplemented with the appropriate substrates. For nitrate reduction, strains were supplemented with $0 \cdot 1$ or $0 \cdot 01 \% \mathrm{NaNO}_{3}$ and $0 \cdot 17 \%$ agar. Cells of strain $37^{\mathrm{T}}$ were Gram-negative, oxidase-positive, weakly catalase-positive and positive for nitrate reduction, all traits characteristic of members of the genus Psychromonas. 
Table 1. Comparison of characteristics of $P$. ingrahamii sp. nov. and other members of the genus Psychromonas

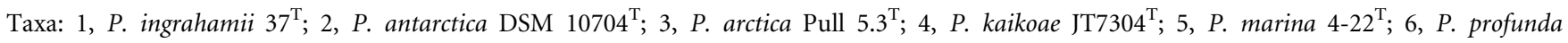
$2825^{\mathrm{T}}$. All were Gram-negative, oxidase-positive, catalase-positive, and able to use D-glucose and D-fructose as sole carbon sources. Characteristics are scored as: +, positive; -, negative; W, weakly positive after 3 weeks; (W), weakly positive after 6 weeks. NR, Not reported; ND, not determined. Data for other Psychromonas species were taken from Breezee et al. (2004), Mountfort et al. (1998), Kawasaki et al. (2002), Nogi et al. (2002), Groudieva et al. (2003), Xu et al. (2003) and Brenner et al. (2005).

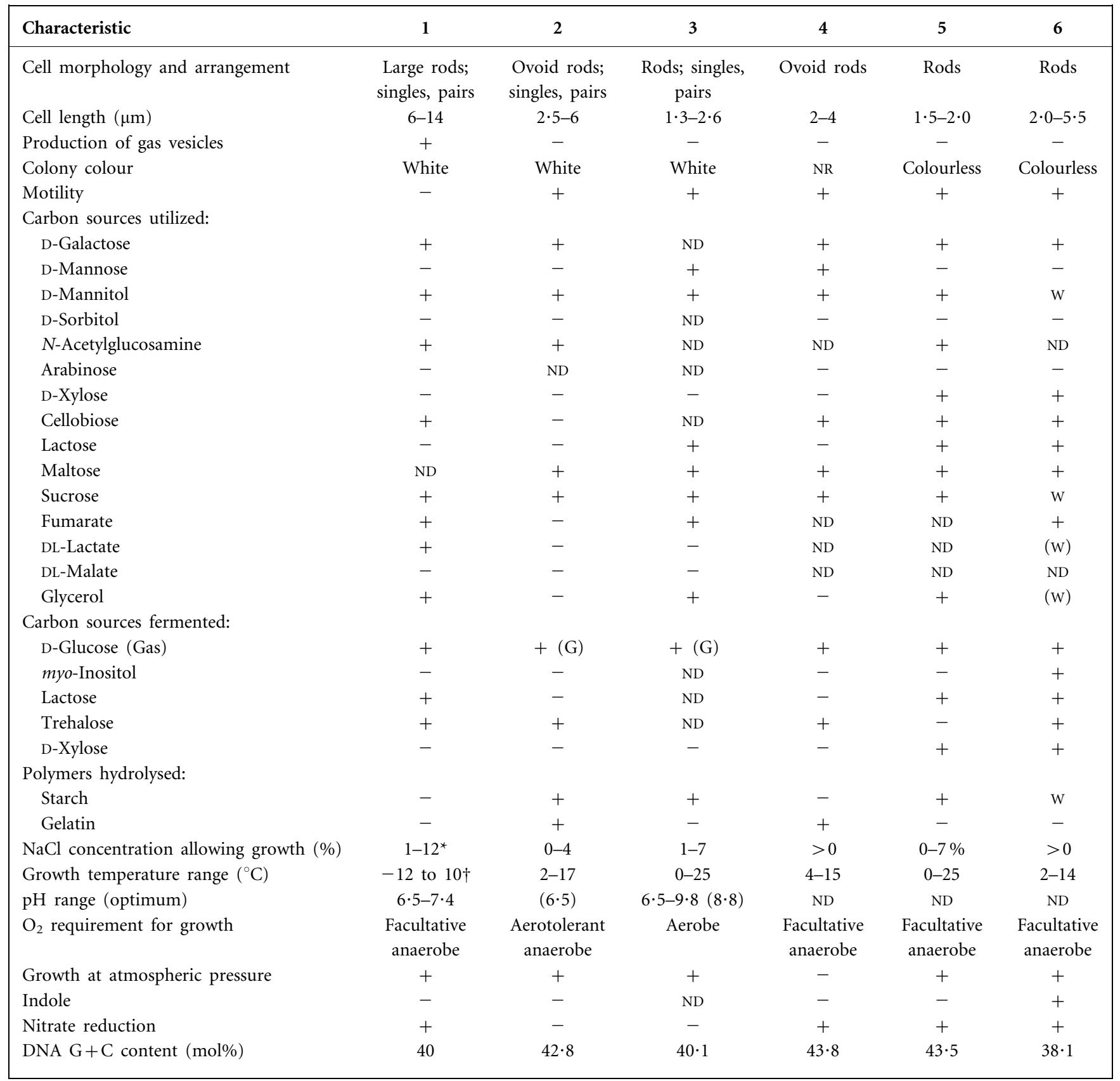

${ }^{*}$ Weak growth was seen at concentrations up to $20 \%$.

$\dagger$ Attempts to grow P. ingrahamii at temperatures below $-12^{\circ} \mathrm{C}$ were inconclusive because the culture medium froze.

However, strain $37^{\mathrm{T}}$ could not hydrolyse starch or gelatin. For determination of indole production, cultures were grown in $\mathrm{SWC}_{\mathrm{m}}$ lacking succinate and were tested at three different stages of growth; indole production was not observed.
The whole-cell fatty acid composition was determined using fatty acid methyl ester analysis of cells grown on $\mathrm{SWC}_{\mathrm{m}}$ plates at $4{ }^{\circ} \mathrm{C}$. Cells were scraped into $13 \times 100 \mathrm{~mm}$ Teflonlined tubes, frozen at $-80^{\circ} \mathrm{C}$ and lysed. The fatty acids were 

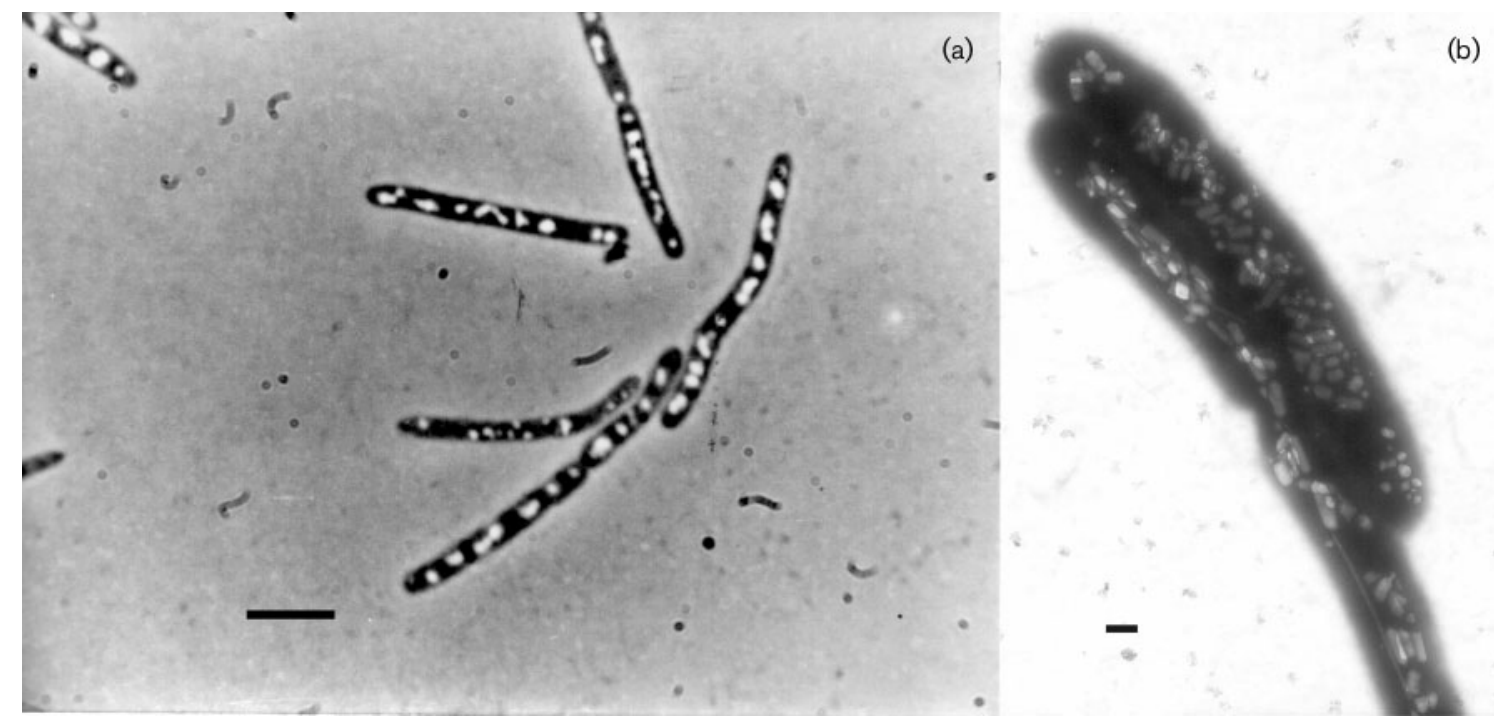

Fig. 1. Phase contrast (a) and transmission electron (b) micrographs of cells of strain $37^{\top}$. Bars, 5 and $0.6 \mu \mathrm{m}$, respectively. Bright areas within the cells observed by phase contrast microscopy are gas vacuoles. The characteristic morphology of the subunit gas vesicles, i.e. their cylindrical shape with conical polar caps, is shown in (b).

saponified with methanolic base, then converted to fatty acid methyl esters with $\mathrm{HCl}$ using the MIDI protocol as previously described (MIDI, 1993). A Hewlett Packard model 5890 Series II gas chromatograph was used to identify and quantify the fatty acid methyl esters. This analysis revealed the principal constituents to be 16-carbon unsaturated and saturated fatty acids $16: 1 \omega 7 c$ and $16: 0$, making up 67 and $18 \cdot 7 \%$, respectively, of the whole-cell fatty acid content. Other Psychromonas species also contain high concentrations of $16: 1$, ranging between $39 \%$ in Psychromonas marina $4-22^{\mathrm{T}}$ and $58 \%$ in P. antarctica DSM $10704^{\mathrm{T}}$ (Table 2). Other fatty acids found in measurable quantities in strain
$37^{\mathrm{T}}$ included 18:1 (3.6\%) and $12: 0(2 \cdot 5 \%)$. Our analysis was unable to distinguish between the fatty acids $12: 0$ alde, $16: 1$ ISO and $14: 03-\mathrm{OH}$, and $4 \cdot 5 \%$ of the fatty acids from strain $37^{\mathrm{T}}$ were among this group. The fatty acid composition of strain $37^{\mathrm{T}}$ is summarized in Table 2 .

Genomic DNA from strain $37^{\mathrm{T}}$ was isolated using a hexadecyltrimethylammonium bromide miniprep protocol (Ausubel et al., 1989). The DNA G $+\mathrm{C}$ content of strain $37^{\mathrm{T}}$ was determined by HPLC according to the method of Mesbah $e t$ al. (1989) and found to be $40 \mathrm{~mol} \%$, within the range of $38 \cdot 1-43 \cdot 8 \mathrm{~mol} \%$ reported for other members of the genus

Table 2. Fatty acid content of $P$. ingrahamii sp. nov. and other members of the genus Psychromonas

Taxa: 1, P. ingrahamii $37^{\mathrm{T}} ; 2$, P. antarctica DSM $10704^{\mathrm{T}} ; 3$, P. arctica Pull $5.3^{\mathrm{T}} ; 4$, P. kaikoae $\mathrm{JT} 7304^{\mathrm{T}} ; 5$, P. marina 4-22 $2^{\mathrm{T}} ; 6$, P. profunda $2825^{\mathrm{T}}$. Values are percentages of total fatty acids. Isomers are shown in parentheses if known. Results below $1 \%$ are not shown. Data for other Psychromonas species were taken from Kawasaki et al. (2002), Nogi et al. (2002), Groudieva et al. (2003) and Xu et al. (2003).

\begin{tabular}{|c|c|c|c|c|c|c|}
\hline Fatty acid & 1 & 2 & 3 & 4 & 5 & 6 \\
\hline $12: 0$ & $2 \cdot 5$ & 1 & $2 \cdot 7-5 \cdot 2$ & 1 & & \\
\hline $14: 0$ & & & & 6 & & \\
\hline $15: 0$ & & & & 1 & & \\
\hline $16: 0$ & $18 \cdot 7$ & 24 & $7 \cdot 0-16 \cdot 2$ & 15 & $43 \cdot 6$ & 31 \\
\hline $14: 1$ & & $8(\omega 7 t)$ & $2 \cdot 7-5 \cdot 2(\omega 5 t)$ & $10(\omega 7 t)$ & $3 \cdot 2$ & 15 \\
\hline $16: 1$ & $67(\omega 7 c)$ & $58(\omega 7 c)$ & $\sim 50(\omega 7 c), 7 \cdot 0-16 \cdot 2(\omega 7 t)$ & $52(\omega 7 c), 2(\omega 9 c)$ & $39 \cdot 4$ & 44 \\
\hline $18: 1$ & $3 \cdot 6$ & $3(\omega 7 c)$ & $7 \cdot 0-16 \cdot 2(\omega 7)$ & $2(\omega 7 c)$ & $3 \cdot 1$ & \\
\hline $20: 5 \omega 3$ & & & & 2 & & \\
\hline $22: 6$ & & & & 2 & $1 \cdot 6$ & \\
\hline $12: 03-\mathrm{OH}$ & & & & 2 & & \\
\hline $\begin{array}{l}12: 0 \text { alde, } 16: 1 \text { ISO } \\
\text { or } 14: 03-\mathrm{OH}\end{array}$ & $4 \cdot 5$ & $6(14: 03-\mathrm{OH})$ & & $4(14: 03-\mathrm{OH})$ & $2 \cdot 7(16: 1$ ISO $)$ & \\
\hline
\end{tabular}


Psychromonas (Mountfort et al., 1998; Kawasaki et al., 2002; Nogi et al., 2002; Groudieva et al., 2003; Xu et al., 2003).

The 16S rRNA gene from strain $37^{\mathrm{T}}$ was sequenced as described by Gosink \& Staley (1995). The EMBL accession numbers for additional $16 \mathrm{~S}$ rRNA gene sequences used for analysis are given in parentheses in Fig. 2. These sequences were aligned using CLUSTAL_X (Thompson et al., 1997). Phylogenetic trees were constructed by determining distances (according to the Kimura two-parameter model) and clustering (with the neighbour-joining method) by using the MEGA (Molecular Evolutionary Genetics Analysis) version 2.1 software package (Kumar et al., 2001). Phylogenetic analysis of the $16 \mathrm{~S}$ rRNA gene sequence revealed that strain $37^{\mathrm{T}}$ was a member of the Gammaproteobacteria, was related most closely to $P$. antarctica DSM $10704^{\mathrm{T}}$, showing $96 \cdot 8 \%$ similarity at the nucleotide level, and clustered with other members of the genus Psychromonas (Fig. 2). Strain $37^{\mathrm{T}}$ was also related closely ( $>98 \%$ sequence similarity) to two other polar sea ice taxa, strain 174 (EMBL accession no. U73722) and strain 90Pgv1 (EMBL accession no. U14582), isolated from the Arctic and Antarctic, respectively, that have not yet been fully characterized (Staley \& Gosink, 1999).

Although strain $37^{\mathrm{T}}$ differed significantly at the phenotypic level from P. antarctica DSM $10704^{\mathrm{T}}$ and other members of the genus Psychromonas (see Table 1), the high degree of $16 \mathrm{~S}$ rRNA gene sequence similarity warranted further examination at the molecular level. DNA-DNA hybridization experiments were performed using the method described by Ziemke et al. (1998), except that for nick translation, $2 \mu \mathrm{g}$ DNA was labelled during $3 \mathrm{~h}$ incubation at $15^{\circ} \mathrm{C}$ using genomic DNA isolated from strain $37^{\mathrm{T}}$ and P. antarctica DSM $10704^{\mathrm{T}}$. The reassociation value between these two strains was $37 \cdot 1 \%$ (reciprocal $38 \cdot 8 \%$ ), confirming that strain $37^{\mathrm{T}}$ represents a novel species, according to accepted criteria (Wayne et al., 1987).
Members of the genus Psychromonas have been isolated from a variety of low-temperature environments, including a high-salinity pond on the McMurdo ice-shelf (Mountfort et al., 1998), deep-sea cold-seep sediments near Japan (Xu et al., 2003; Nogi et al., 2002), Japanese cold-current coastal sea water (Kawasaki et al., 2002), and northern European Arctic sea water and sea ice (Groudieva et al., 2003). Members of this genus display great phenotypic diversity, ranging in degrees of piezophily and temperature range of growth. Strain $37^{\mathrm{T}}$, isolated from a sea ice core, represents a novel species within this genus and is unique among this group in its unusually large cell size, its ability to grow at subfreezing temperatures, its tolerance to high salt concentrations and its ability to produce gas vacuoles (see Table 1). Unlike other Psychromonas strains, strain $37^{\mathrm{T}}$ cannot hydrolyse the polymers starch or gelatin and appears to be non-flagellated.

The abilities of strain $37^{\mathrm{T}}$ to withstand both high salt concentrations and subfreezing temperatures are consistent with the polar sea ice environment from which it was isolated. The semisolid matrix of polar sea ice consists of ice crystals around which extruded brine accumulates to high concentrations. The high salt concentrations within these brine pockets allow the water to remain liquid at temperatures well below freezing. It is within these high-salt, low-temperature microenvironments that members of the SIMCOs persist.

Although the formation of gas vacuoles by strain $37^{\mathrm{T}}$ is unique among members of the Psychromonas genus, it is not unusual for a polar sea ice bacterium. Within the SIMCOs, gas vacuolate bacteria are abundant and phylogenetically diverse, with representatives in the Alpha-, Beta- and Gammaproteobacteria, and within the phylum Bacteroidetes (Gosink et al., 1993; Gosink \& Staley, 1995; Irgens et al., 1989). Strain $37^{\mathrm{T}}$ is unusual, however, in its ability to produce two distinct gas vacuole morphotypes within a single

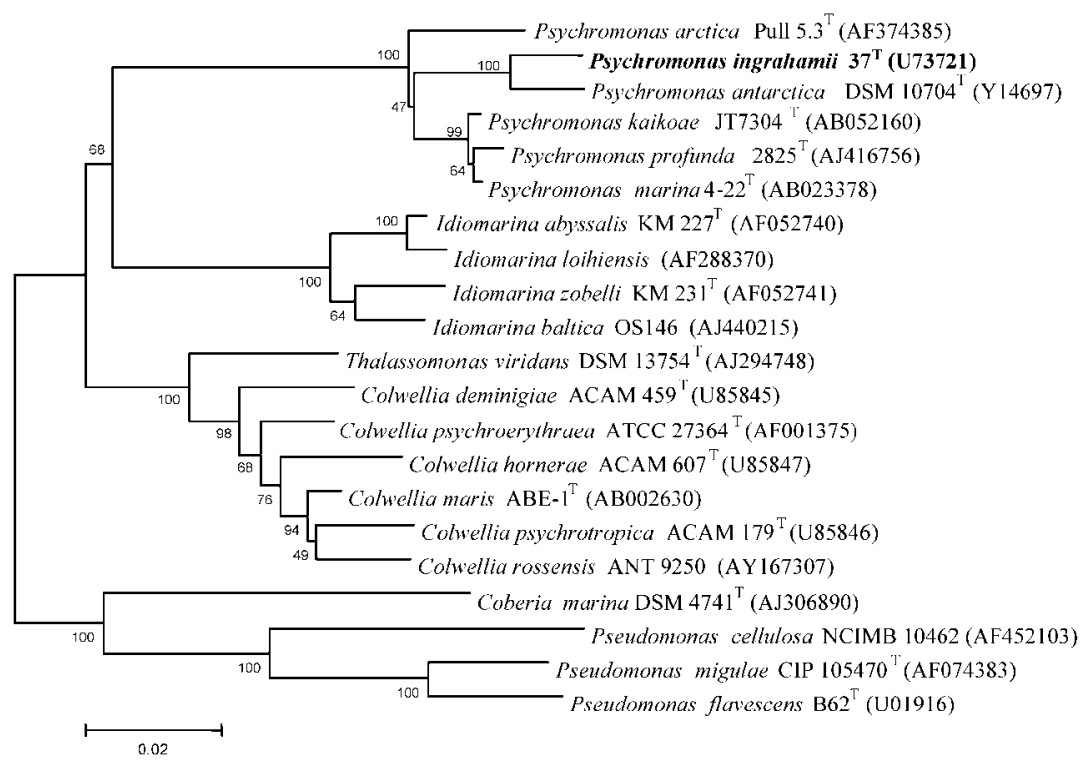

Fig. 2. Phylogenetic analysis based on $16 \mathrm{~S}$ rRNA gene sequences available from the European Molecular Biology Laboratory database (accession numbers are given in parentheses), constructed after multiple alignment of data by using CLUSTAL_X (Thompson et al., 1997). Distances (distance options according to the Kimura two-parameter model) and clustering with the neighbour-joining method were determined by using the software package MEGA (Molecular Evolutionary Genetics Analysis) version 2.1 (Kumar et al., 2001). Bootstrap values, based on 1000 replications, are given as percentages at branch points. Bar, 0.02 substitutions per mean nucleotide position. 
cell, previously reported only in a halophilic archaeon (Walsby, 1994).

Unlike Psychromonas kaikoae $\mathrm{JT} 7304^{\mathrm{T}}$ and P. marina $4-22^{\mathrm{T}}$, strain $37^{\mathrm{T}}$ cell membranes contain no measurable amounts of polyunsaturated fatty acids (PUFAs) such as 20:5 (eicosapentaenoic acid) or 22:6 (docosahexaenoic acid). As the concentration of PUFAs has been suggested to be inversely proportional to optimum growth temperature, the lack of PUFAs in strain $37^{\mathrm{T}}$, which grows at subfreezing temperatures lower than those of other Psychromonas species, is inconsistent with this hypothesis (Bowman et al., 1998c).

Phylogenetic analysis of $16 \mathrm{~S}$ rRNA gene sequences indicated that strain $37^{\mathrm{T}}$, isolated from sea ice from Point Barrow, Alaska, was most closely related to $P$. antarctica DSM $10704^{\mathrm{T}}$, isolated from a high-salinity pond sediment $(96 \cdot 8 \%$ sequence similarity). Strain $37^{\mathrm{T}}$ was also closely related to two polar sea ice taxa, 174 and 90Pgv1, isolated from Arctic and Antarctic sea ice, respectively (Staley \& Gosink, 1999). It is interesting that such closely related organisms have been isolated from opposite polar regions. This phenomenon has been shown previously for other sea ice genera, including Polaribacter and Octadecabacter (Gosink et al., 1997, 1998), and is supported by studies of Arctic and Antarctic sea ice communities using culture-independent molecular techniques (Brown \& Bowman, 2001; Brinkmeyer et al., 2003). This suggests that organismal dispersal was followed by acquisition of traits required for adaptation to particular microenvironments.

\section{Description of Psychromonas ingrahamii sp. nov.}

Psychromonas ingrahamii (in.gra.ham'.i.i. N.L. gen. n. ingrahamii of Ingraham, in honour of John L. Ingraham for his extensive research on psychrophilic bacteria).

Cells are Gram-negative, non-motile large rods, 6-14 $\mu \mathrm{m}$ long and $1 \cdot 25-1 \cdot 5 \mu \mathrm{m}$ wide, found either singly or in pairs, and containing two gas vesicle morphotypes. On $\mathrm{SWC}_{\mathrm{m}}$, colonies are white, circular, smooth and convex, with an entire margin. Moderately halophilic (growth at $\mathrm{NaCl}$ concentrations of $1-12 \%$, with weak growth up to $20 \%$, but no growth without $\mathrm{NaCl}$ ), and strictly psychrophilic. Temperature range for growth is $-12{ }^{\circ} \mathrm{C}$ (with a generation time of $240 \mathrm{~h}$ ) or lower (not tested) to $10^{\circ} \mathrm{C}$ or higher (not tested between 10 and $15^{\circ} \mathrm{C}$, but no growth is observed at $15^{\circ} \mathrm{C}$ ). The $\mathrm{pH}$ range for growth is $6 \cdot 5-7 \cdot 4$. Grows at atmospheric pressure. Facultative anaerobe, capable of both respiratory and fermentative metabolism. Catalase- and cytochrome oxidase-positive. Reduces inorganic nitrate. Indole test is negative. Predominant cellular fatty acids are $16: 1 \omega 7 c$ and 16:0. Utilizes as sole carbon sources D-glucose, D-ribose, D-fructose, sucrose, L-glutamate, L-cysteine, DL-aspartate, fumarate, succinate, pyruvate, propionate, acetate, glycerol, $\mathrm{N}$-acetylglucosamine, glucosamine, cellobiose, DL-lactate, D-mannitol, salicin, trehalose and D-glucuronate, but not lactose, L-leucine, L-proline, $\alpha$-ketoglutarate, citrate, benzoate, glycolate, methanol, arabinose, caproate, D-gluconate, myo-inositol, DL-malate, D-mannose, D-sorbitol or Dxylose. Can ferment lactose, sucrose, D-mannitol, salicin, maltose, trehalose, cellobiose, D-galactose, melibiose and D-glucose (without gas production), but not dulcitol, myoinositol, D-sorbitol, L-arabinose or D-xylose. No starch or gelatin hydrolysis. The DNA G +C content is $40 \mathrm{~mol} \%$.

The type and only strain, $37^{\mathrm{T}}\left(=\right.$ CCUG $51855^{\mathrm{T}}=$ CIP $108865^{\mathrm{T}}$ ), was isolated from Elson Lagoon (Point Barrow, Alaska, USA) about $130 \mathrm{~cm}$ from the ice-water interface from a $1.8 \mathrm{~m}$ ice core.

\section{Acknowledgements}

This work was supported in part by NSF grant BSR 9006788, the University of Washington (UW) NSF IGERT DGE-9870713 as well as the UW NASA NAI programs. We thank Margaret L. Hudson at Seattle University (Seattle, WA) for assisting with transmission electron microscopy.

\section{References}

Ausubel, F. M., Brent, R., Kingston, R. L., Moore, D. D., Seidman, J. G., Smith, L. A. \& Struhl, K. (editors) (1989). Current Protocols in Molecular Biology. New York: Wiley.

Bowman, J. P. \& Nichols, D. S. (2002). Aequorivita gen. nov., a member of the family Flavobacteriaceae isolated from terrestrial and marine Antarctic habitats. Int J Syst Evol Microbiol 52, 1533-1541.

Bowman, J. P., McCammon, S. A., Brown, J. L., Nichols, P. D. \& McMeekin, T. A. (1997). Psychroserpens burtonensis gen. nov., sp. nov., and Gelidibacter algens gen. nov., sp. nov., psychrophilic bacteria isolated from antarctic lacustrine and sea ice habitats. Int J Syst Bacteriol 47, 670-677.

Bowman, J. P., McCammon, S. A., Lewis, T., Skerratt, J. H., Brown, J. L., Nichols, D. S. \& McMeekin, T. A. (1998a). Psychroflexus torquis gen. nov., sp. nov., a psychrophilic species from Antarctic sea ice, and reclassification of Flavobacterium gondwanense (Dobson et al. 1993) as Psychroflexus gondwanense gen. nov., comb. nov. Microbiology 144, 1601-1609.

Bowman, J. P., McCammon, S. A., Brown, J. L. \& McMeekin, T. A. (1998b). Glaciecola punicea gen. nov., sp. nov. and Glaciecola pallidula gen. nov., sp. nov.: psychrophilic bacteria from Antarctic sea-ice habitats. Int J Syst Bacteriol 48, 1213-1222.

Bowman, J. P., Gosink, J. J., McCammon, S. A., Lewis, T. E., Nichols, D. S., Nichols, P. D., Skerratt, J. H., Staley, J. T. \& McMeekin, T. A. (1998c). Colwellia demingiae sp. nov., Colwellia hornerae sp. nov., Colwellia rossensis sp. nov. and Colwellia psychrotropica sp. nov.: psychrophilic Antarctic species with the ability to synthesize

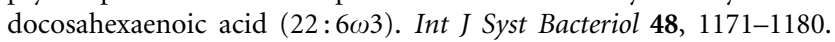

Bowman, J. P., Nichols, C. M. \& Gibson, J. A. E. (2003). Algoriphagus ratkowskyi gen. nov., sp. nov., Brumimicrobium glaciale gen. nov., sp. nov., Cryomorpha ignava gen. nov., sp. nov. and Crocinitomix catalasitica gen. nov., sp. nov., novel flavobacteria isolated from various polar habitats. Int J Syst Evol Microbiol 53, 1343-1355.

Breezee, J., Cady, N. \& Staley, J. T. (2004). Subfreezing growth of the sea ice bacterium 'Psychromonas ingrahamii'. Microbiol Ecol 47, 300-304.

Brenner, D. J., Krieg, N. R., Staley, J. T. \& Garrity. G. M. (editors) (2005). Genus XII. Psychromonas, Mountfort, Rainey, Burghardt, 
Kaspar, and Stackebrandt 1998b, 631 ${ }^{\mathrm{VP}}$ emend. In Bergey's Manual of Systematic Bacteriology, vol. 2B, pp. 278-480. New York: Springer.

Brinkmeyer, R., Knittel, K., Jurgens, J., Weyland, H., Amann, R. \& Helmke, E. (2003). Diversity and structure of bacterial communities in Arctic versus Antarctic pack ice. Appl Environ Microbiol 69, 6610-6619.

Brown, M. V. \& Bowman, J. P. (2001). A molecular phylogenetic survey of sea-ice microbial communities (SIMCO). FEMS Microbiol Ecol 35, 267-275.

Dyksterhouse, S. E., Gray, J. P., Herwig, R. P., Lara, J. C. \& Staley, J. T. (1995). Cycloclasticus pugetii gen. nov., sp. nov., an aromatic hydrocarbon-degrading bacterium from marine sediments. Int J Syst Bacteriol 45, 116-123.

Eicken, H. (1992). The role of sea ice in structuring Antarctic ecosystems. Polar Biol 12, 3-13.

Garrison, D. L., Ackley, S. F. \& Buck, K. R. (1983). A physical mechanism for establishing algal populations in frazil ice. Nature 306, 363-365.

Gerhardt, P., Murray, R. G. E., Costilow, R. N., Nester, E. W., Wood, W. A., Krieg, N. R. \& Phillips, G. B. (1981). Manual of Methods for General Bacteriology. Washington, DC: American Society for Microbiology.

Gosink, J. J. \& Staley, J. T. (1995). Biodiversity of gas vacuolate bacteria from Antarctic sea ice and water. Appl Environ Microbiol 61, 3486-3489.

Gosink, J. J., Irgens, R. L. \& Staley, J. T. (1993). Vertical distribution of bacteria from arctic sea ice. FEMS Microbiol Ecol 102, 85-90.

Gosink, J. J., Herwig, R. P. \& Staley, J. T. (1997). Octadecabacter arcticus gen. nov., sp. nov., and $O$. antarcticus sp. nov., nonpigmented, psychrophilic gas vacuolated bacteria from polar sea ice and water. Syst Appl Microbiol 20, 356-365.

Gosink, J. J., Woese, C. R. \& Staley, J. T. (1998). Polaribacter gen. nov., with three new species, $P$. irgensii sp. nov., $P$. franzmannii $\mathrm{sp}$. nov. and $P$. filamentus sp. nov., gas vacuolate polar marine bacteria of the Cytophaga-Flavobacterium-Bacteroides group and reclassification of 'Flectobacillus glomeratus' as comb. nov. Int J Syst Bacteriol 48, 223-235.

Groudieva, T., Grote, R. \& Antranikian, G. (2003). Psychromonas arctica sp. nov., a novel psychrotolerant, biofilm-producing bacterium isolated from Spitzbergen. Int J Syst Evol Microbiol 53, 539-545.

Irgens, R. L., Suzuki, I. \& Staley, J. T. (1989). Gas vacuolate bacteria obtained from marine waters of Antarctica. Curr Microbiol 18, 261-265.

Irgens, R. L., Gosink, J. J. \& Staley, J. T. (1996). Polaromonas vacuolata gen. nov., sp. nov., a psychrophilic, marine, gas vacuolate bacterium from Antarctica. Int J Syst Bacteriol 46, 822-826.

Ivanova, E. P., Flavier, S. \& Christen, R. (2004). Phylogenetic relationships among marine Alteromonas-like proteobacteria: emended description of the family Alteromonadaceae and proposal of Pseudoalteromonadaceae fam. nov., Colwelliaceae fam. nov., Shewanellaceae fam. nov., Moritellaceae fam. nov., Ferrimonadaceae fam. nov., Idiomarinaceae fam. nov. and Psychromonadaceae fam. nov. Int J Syst Evol Microbiol 54, 1773-1788.

Junge, K., Gosink, J. J., Hoppe, J. \& Staley, J. T. (1998). Arthrobacter, Brachybacterium, and Planococcus isolates identified from Antarctic sea ice brine. Description of Planococcus momeekinii, sp. nov. Syst Appl Microbiol 21, 306-314.
Kawasaki, K., Nogi, Y., Hishinuma, M., Nodasaka, Y., Matsuyama, H. \& Yumoto, I. (2002). Psychromonas marina sp. nov., a novel halophilic, facultatively psychrophilic bacterium isolated from the coast of the Okhotsk Sea. Int J Syst Evol Microbiol 52, 1455-1459.

Kumar, S., Tamura, K., Jakobsen, I. B. \& Nei, M. (2001). MEGA2: Molecular Evolutionary Genetics Analysis software. Bioinformatics 17, 1244-1245.

Maykut, G. A. (1985). The ice environment. In Sea Ice Biota, pp. 21-82. Edited by R. A. Horner. Boca Raton, FL: CRC Press.

Mesbah, M., Premachandran, U. \& Whitman, W. B. (1989). Precise measurement of the $\mathrm{G}+\mathrm{C}$ content of deoxyribonucleic acid by highperformance liquid chromatography. Int J Syst Bacteriol 39, 159-167.

MIDI (1993). Microbial Identification System Operating Manual, version 4. Newark, DE: MIDI.

Morita, R. Y. (1975). Psychrophilic bacteria. Bacteriol Rev 39, 146-167.

Mountfort, D. O., Rainey, F. A., Burghardt, J., Kaspar, H. F. \& Stackebrandt, E. (1998). Psychromonas antarcticus gen. nov., sp. nov., a new aerotolerant anaerobic, halophilic psychrophile isolated from pond sediment of the McMurdo Ice Shelf, Antarctica. Arch Microbiol 169, 231-238.

Nichol, S. \& Allison, I. (1997). The frozen skin of the southern ocean. Am Sci 85, 426-439.

Nogi, Y., Kato, C. \& Horikoshi, K. (2002). Psychromonas kaikoae sp. nov., a novel piezophilic bacterium from the deepest coldseep sediments in the Japan Trench. Int J Syst Evol Microbiol 52, 1527-1532.

Parkinson, C. L. \& Gloersen, P. (1993). Global sea ice coverage. In Atlas of Satellite Observations Related to Global Change, pp. 371-383. Edited by R. J. Gurney, J.-L. Foster \& C. L. Parkinson. Cambridge: Cambridge University Press.

Staley, J. T. (1980). The gas vacuole: an early organelle of prokaryotic motility. Origins Life 10, 111-116.

Staley, J. T. \& Gosink, J. J. (1999). Poles apart: biodiversity and biogeography of sea ice bacteria. Annu Rev Microbiol 53, 189-215.

Staley, J. T., Irgens, R. L. \& Herwig, R. P. (1989). Gas vacuolate bacteria found in Antarctic sea ice with ice algae. Appl Environ Microbiol 55, 1033-1036.

Thompson, J. D., Gibson, T. J., Plewniak, F., Jeanmougin, F. \& Higgins, D. G. (1997). The CLUSTAL_X windows interface: flexible strategies for multiple sequence alignment aided by quality analysis tools. Nucleic Acids Res 25, 4876-4882.

Walsby, A. E. (1972). Structure and function of gas vacuoles. Bacteriol Rev 36, 1-32.

Walsby, A. E. (1994). Gas vesicles. Microbiol Rev 58, 94-144.

Wayne, L. G., Brenner, D. J., Colwell, R. R. \& 9 other authors (1987). Report of the ad hoc committee on reconciliation of approaches to bacterial systematics. Int J Syst Bacteriol 37, 463-464.

Weeks, W. F. \& Ackley, S. F. (1982). The Growth, Structure, and Properties of Sea Ice. CRREL monograph 82-1. Hanover, NH: US Army Cold Regions Research and Engineering Laboratory.

Xu, Y., Nogi, Y., Kato, C., Liang, Z., Ruger, H.-J., De Kegel, D. \& Glansdorff, N. (2003). Psychromonas profunda sp. nov., a psychropiezophilic bacterium from deep Atlantic sediments. Int J Syst Evol Microbiol 53, 527-532.

Ziemke, F., Höfle, M. G., Lalucat, J. \& Rossello-Mora, R. (1998). Reclassification of Shewanella putrefaciens Owen's genomic group II as Shewanella baltica sp. nov. Int J Syst Bacteriol 48, 179-186. 